\title{
Re-thinking public health: Towards a new scientific logic of routine animal health care in European industrial farming
}

\author{
Camille Bellet ${ }^{1 凶}$, Lindsay Hamilton ${ }^{2}$ \& Jonathan Rushton ${ }^{3}$
}

This study makes the case for a new scientific logic of routine animal health care in industrial farming in Europe. We argue that the social regime underpinning scientific research and development on chronic animal disease management (CADM) in Europe stifles innovation and sustains a productivist model of animal husbandry that facilitates and maintains chronic animal diseases rather than eliminating them. Drawing on documentary analysis and qualitative interviews, the study explores the science of CADM in the broiler, cattle and pig sectors of the European food industry. Our findings show that in these major sectors, research and development on CADM is largely orientated towards a logic of growth, profitability and control rather than a recognition of the interconnection between chronic animal diseases, the food industry, and people (especially consumers) as advocated by the One Health approach. The study contributes to the literature on medical humanities and science and technology studies within One Health and public health in two ways: First, we draw new focus towards chronic animal diseases that are non-transmissible to humans and argue that while these are not zoonoses, they are equally worthy of attention for managing the emergence of new pathogens and diseases. Second, we expand the conceptualisation of One Health to include chronic animal health conditions. Our argument is that public health as an outcome of the One Health approach should be a term of reference that applies to humans and nonhumans alike whether they be farmed animals, practitioners or consumers.

\footnotetext{
${ }^{1}$ Centre for the History of Science, Technology and Medicine, University of Manchester, Manchester, UK. ${ }^{2}$ The York Management School, University of York, York, UK. ${ }^{3}$ Institute of Infection, Veterinary and Ecological Sciences, University of Liverpool, Liverpool, UK. The literature review and the interviews were conducted while CB was at The Institute of Infection, Veterinary and Ecological Sciences, University of Liverpool, UK.

凶email: camille.bellet@manchester.ac.uk
} 


\section{Introduction}

he governance of public health and infectious disease risk is currently under intense scrutiny. Urbanisation, industrialisation and globalisation have considerably increased the risk and scale of public health crises associated with antimicrobial resistance ('AMR') and pandemic disease outbreaks (LePan, 2020). In the past two decades, in particular, the frequency of public health crises associated with emerging and reemerging infectious diseases have been higher than ever before (Lashley, 2006) following the emergence and spread of the West Nile virus in the 2000s (Gubler, 2007), SARS (Cherry and Krogstad, 2004), bird flu (Conly and Johnston, 2004), swine flu (Farley, 2010), MERS (Al Hajjar et al., 2013), Ebola (Kaner and Schaack, 2016), Zika (Troncoso, 2016), and now COVID-19 which, as of 28 June 2021, has infected 180,817,269 people and killed 3,923,238 (WHO, 2020). While it is not possible to demonstrate a clear 'natural' origin of COVID-19 (Wade, 2021), pandemics, in general, often emerge from cross-contamination of pathogens between human and nonhuman animal species (Andersen et al., 2020; Pike et al., 2010; Roger et al., 2021). This situation is relevant to our focus on farmed animal health in this paper because agriculture is a place where the risk of emergence and transmission of pathogens between human and nonhuman animals is ever-present.

Often pressed against wildlife habitats (Spinney, 2020; Standaert, 2020), farmed animals are ideal intermediate hosts for the recombination, reassortment and transmission of pathogens to humans (Wallace, 2009). In large-scale industrial systems of animal production; that is, systems that prioritise high animal density, low genetic diversity, short production cycles, productivity and continuous movements of animals between farm businesses, opportunities for human and animal pathogens to infect, mutate, recombine, and spread internationally (Wallace, 2009 ) increase. This has already been demonstrated by the two flu pandemics of 2004 and 2009 (Wallace, 2009; Wallace and Wallace, 2015). Despite recent research on the links between public health and industrial farming (Wallace et al., 2015; Bellet, 2018; Kirchhelle, 2018) and between industrial farming and chronic animal diseases (Woods, 2014; Bonnaud and Fortané, 2020; Fortané, 2020), the link between public health and chronic animal diseases-and more specifically between public health and the science of chronic animal disease management ('CADM') in industrial farming-is under-explored in contemporary research. This article seeks to address this gap by exploring the value of 'One Health' as a means to see public health across species borderlines and facilitate a 'rounded vision' (Pickersgill et al., 2018, p. 1462) of health and wellbeing as a multi-agent issue.

In this article, we demonstrate that the social regime underpinning scientific research and development on CADM in Europe encourages a logic of routine animal health care in industrial farming which intersects the risk of disease emergence and pandemics by influencing the ways in which researchers (in this case, animal health scientists or 'AHS') explore, understand, and guide CADM in industrial farming. What AHS choose to focus on, include or exclude from their research, analyses and discourses on chronic animal health conditions embodies a 'social decision' (Wallace and Wallace, 2015, p. 2077) and 'sociocultural meanings' (Lupton, 2000, p. 52) that have significant implications for the ways chronic animal diseases are comprehended and managed in industrial settings (Cassidy, 2017; Enticott and Ward, 2020). Adding new animal-oriented insights to extant research in the sociology of medical knowledge (Foucault, 1975, 1989; Fairclough, 1992; Lupton, 1994, 2000; Mol, 2008), we draw upon Latimer's (2019) concept of 'science under siege' to examine the underlying norms and values governing the production of scientific knowledge on CADM and explore 'conditions of possibility (p. 264) for a new scientific logic of routine animal health care that reorients industrial practices toward 'more-than-human solidarity' in public health (Rock and Degeling, 2015).

By exposing practices that 'silently incorporate' an ideal of CADM, animal health care and taking 'good care' (Mol, 2008) of farmed animal health conditions, we present findings that are fundamental to prevent the emergence and re-emergence of new diseases (Hinchliffe et al., 2013; Allen et al., 2017) and future pandemics (Tomley and Shirley, 2009; Wallace, 2009). The article begins, therefore, by situating the importance of the science of CADM in accounts of public health and One Health literatures. We then examine our methodology before turning to our empirical results. Finally, we draw out the implications of our findings for a new, more-than-human order in public health and scientific knowledge in industrial farming.

\section{Animal health, public health and the food industry}

Farmed animal health has historically been the motive upon which AHS have built their identity and defended their social status as public health experts in Europe (Bonnaud and Fortané, 2020). With the help of public authorities, scientific knowledge on highly contagious and zoonotic farmed animal diseases, such as trichinosis, swine fever, and tuberculosis (Berdah, 2010; Barroux, 2011; Woods, 2013; Mitsuda, 2017) has been the backbone of European food policies for safeguarding food standards and hygiene, global economies and human health since the late 19th century. At the same time, the production of scientific knowledge on chronic and non-zoonotic farmed animal diseases, such as cattle lameness and broiler enteritis, has been relegated to the private sector as part of day-to-day farm business management (Lowe, 2009; Woods, 2013).

Chronic animal diseases are persistent animal diseases affecting animal health and wellbeing, which are ostensibly harmless to human health but which have lasting effects on farmed animals productivity and profit' (Woods, 2019, p. 2). They are intrinsically linked to intensive modes of animal husbandry (Nir, 2003) whereby farmed animals are mainly kept indoors at high stocking densities and represent, according to Wallace (2016), an important source of farming pathogens with 'pandemic potential' ( $p$. 81). Chronic animal diseases are characterised by 'complex aetiologies, low mortality, [and] mild clinical signs' (Woods, 2019 , p. 6). They are often silent too, which makes scientific research and 'the discourse of science' (Lupton, 2000) a founding element of their day-to-day management (Enticott and Ward, 2020; Woods, 2019).

In recent years, the crisis of antimicrobial resistance (AMR) has prompted public authorities to reinstate routine treatment for chronic animal health conditions in farming as a central part of the 'One Health' approach (Bonnaud and Fortané, 2016; Cassidy, 2017); the idea of caring for an animal, human and environmental health as one to prevent future health crises and social harms (Cassidy, 2017). However, as Cassidy (2017) points out, 'knowledge about and concern for animals in their own right does not appear to be a major topic of interest in One Health' (p. 197): chronic animal diseases and their treatment remain a source of human infection or food scarcity but by no means a direct concern of One Health like their human counterparts. In our view, this would require One Health to consider the origins of chronic animal health issues and address the systemic and, most often, human forms of animal ill-being in industrial farming at the origin of crises such as AMR, such as 'the rise of consumerism' (Lowe et al., 2008). 
Public health critics (Rock et al., 2014; Friese and Nuyts, 2017; Andrews and Duff, 2019) have stated that the human-centered vision of health, diseases, and health care in One Health is deeply problematic because it advocates for a 'logic of care' (Mol et al., 2010) that reinforces 'the very anthropocentrism that it seeks to change' (Cassidy, 2017, p. 197) and prevents humans from understanding and transforming a relationship with animals that could improve the health of humans and animals together (Rock et al., 2014; Friese and Nuyts, 2017), including mitigating the risk of current and future pandemics (Wallace et al., 2015). 'Another science' (Stengers, 2018) of One Health that is 'meaningful and sustainable' for limiting future harms and diseases emerging from animal husbandry is, we argue, desirable for public health but demands innovation (Rock et al., 2014, p. 337), especially in the science of CADM and routine animal health care in industrial farming. Mol et al. (2010) summarise this as an effort 'to contribute to the vitality of the logic of care' (p. 7) in animal husbandry.

Chronic animal diseases are 'sentinels' (LeBoeuf, 2011; Rock et al., 2014) of systems of animal 'subordination and domination' (Wadiwel, 2015, p. 9), and their management an opportunity to prevent public health risks by reviewing the forms of human-animal living-together, especially in the context of food production, consumption and animal husbandry. Our work is part of a growing recognition of the importance of human-animal relations in the construction of One Health and public health (Rock et al., 2014; Friese and Nuyts, 2017; Brown and Nading, 2019; Kirk et al., 2018; Davies et al., 2020). It illuminates scientific aspects of routine animal health care in industrial farming which have been downgraded and relegated to the private domain of food production (Tomley and Shirley, 2009; Enticott et al., 2011) with 'a risk that they will be eroded' by being 'submitted to rules and regulations that are alien to them' (Mol et al., 2010, p. 7). In considering this argument, our purpose here is to critique the dominant and historically embedded scientific logic of CADM and routine animal health care in industrial farming.

\section{Methodology}

While great socio-cultural differences exist in farm veterinary services in Europe, Lowe et al. (2008) argue that the liberalisation of industrial animal production has made research and development in agriculture no longer so 'state-regulated and supported' but rather driven by 'international trade regimes' (p. 227). Our research explores the scientific logic of CADM and routine animal health care in industrial farming in Europe resulting from this 'process of [research] globalisation' (Lowe et al., 2008, p. 227). We used inductive, constructive grounded theory methods (Charmaz, 2009) to explore the discourse of science as it is expressed in relation to CADM in Europe.

Our research examined two extremely common chronic animal diseases, digestive and respiratory, which constitute a major reason for routine animal health care in industrial farming (Woods, 2019). We focus on three sectors of the European food industry: industrial chickens ('broilers'), cattle, and pigs. Largescale production of broilers, cattle, and pigs are common in Europe (Robinson et al., 2014) and chronic digestive and respiratory diseases have become a major issue not only for the European food industry (Rowan et al., 2004; Anonymous, 2015; Jones et al., 2019) but also for the general public in Europe because of their links with animal welfare (Husu-Kallio, 2008; Lawrence, 2016). Because our study was concerned by the social and political nature of research 'agendas' (Latimer, 2019) on CADM in industrial farming, our analysis was predominantly qualitative and rested upon two stages of data collection.
Drawing on previous work exploring scientific representation in research practices and 'iconography in scientific text' (Bastide, 1990; see also, Lupton, 2000; Cassidy, 2017; Friese and Nuyts, 2017), we first conducted a bibliometric search to explore how CADM is imagined and represented by animal health scientists in industrial farming. As previous work has shown, the language of science in publications is both 'powerful' (Lupton, 2000, p. 52) and a 'technique of visualisation' (Bastide, 1990, p. 189) of broader systems of knowledge production-meaning that surveying scientific publications provides a way to uncover or deconstruct (Lupton, 2000, p. 52) the sociocultural values and understandings that underpin research and knowledge production. In other words, a bibliometric approach can help focus collective attention on what should matter in the field concerned (in this case, CADM in industrial farming), as well as identifying gaps and absences in the literature. As Bastide (1990) argues, scientific publications can 'make one see what is invisible' (p. 189, emphasis original) (for example, the immunological trace of infection) and therefore neutralise the way in which complex and mostly invisible phenomena such as chronic digestive and respiratory diseases (Nir, 2003; Woods, 2019) may be understood by the wider community of scientists, farmers, veterinary surgeons, policy-makers, and other practitioners. In sum, examining a broad cross-section of literature in this field aimed to identify the way that AHS study and understand chronic animal diseases in the large-scale broiler, cattle, and pig production in Europe. The question was how AHS perceive these diseases, prioritise them within research projects, render them 'visible' (Bastide, 1990), and how they relate to industrial stakeholders, specifically the food industry. We question what management policies their research supports and what this tells us about the relative priority given to CADM and routine animal health care in industrial farming in Europe.

We used a search string and two bibliographic databases (Web of Science and Scopus) to identify literature used for farmed animal health 'decision-making and planning' in Europe (see Rushton et al., 2018). The search focused on the most common agents of the selected diseases in Europe (Christianson and Joo, 1994; Nicholas and Ayling, 2003; Villareal et al., 2010; Peek et al., 2017; Jones et al., 2019) and fifteen leading European producers of industrial broiler, cattle, and pig production (Eurostat, 2020a, 2020b, 2020c) where chronic animal health conditions are the most concerning (Brockmeier et al., 2002; Yegani and Korver, 2008). The search also included common scientific names of diseases, such as 'coccidiosis' and 'necrotic enteritis' for chronic digestive diseases in broilers. All publications written in English, French, German, Italian and Spanish were included in the analysis. Duplicates $(N=5275)$ were removed, the remaining references $(N=4241)$ were checked for relevance based on publication access, language, geographical area, disease, population, and information for decision-making and planning, as provided in titles and abstracts (see Table 3, Supplementary Material for a summary of the inclusion and exclusion criteria used to select the scientific publications). We read the full texts of the selected references $(N=290)$. Additional publications $(N=10)$ were also identified through reference tracking. A total of 118 scientific publications were included in the analysis (see Supplementary Material for the list of the scientific publications included in the analysis).

In the second step, we conducted in-depth interviews with animal health scientists ('AHS') and other practitioners to deepen our understanding of the scientific representation of and research practices on CADM in industrial farming in Europe. Interviews explored the logics and institutional and organisational circumstances' (Fairclough, 1992, p. 4) of the production of scientific knowledge for CADM in Europe. Interviews were conducted with 
18 farm animal health practitioners engaged in research for CADM or farm animal health decision-making. Participants were recruited within a larger European project (SAPHIR, 2020) looking at CADM. They included 11 AHS (8 from the public sector and 3 from the private sector), 4 veterinary surgeons ('VS'), and 3 policy-makers ('PM'). The majority of the practitioners were based in France, but all were working in the field of CADM research and development with other European countries, in particular Belgium, Germany, Italy, Poland, Spain, Sweden, The Netherlands and the UK. Practitioners worked either in the broiler $(N=9)$ or the cattle $(N=9)$ sector but 8 also had experience in the pig sector. Half of the practitioners were women (though the relevance of gender was not evident in our findings). Ethical approval for this research was granted by the University of Liverpool, former Institute of Infection and Global Health Research Ethics Committee in November 2018. All practitioners were informed about the research and given assurances about anonymity following the Committee on Publication Ethics (COPE) guidance. The interviews were audio-recorded and transcribed verbatim. Most interviews took $90 \mathrm{~min}$ but some were significantly longer ( $150 \mathrm{~min})$. The interview questions started with broad questions related to industrial farming, CADM, routine animal health care in industrial farming to then focus on the science of the selected diseases; their origins, social values, studies, and routine management.

Interviews were analysed qualitatively using a descriptive, reflexive, and iterative approach to coding (Charmaz, 2009). Scientific publications were analysed in parallel with descriptive and interpretative approaches so that we could locate emerging themes from the interviews within larger AHS discourses and practices identified in the selected publications (Charmaz, 2009). The authors discussed and agreed the coding of the dataset, contextualising it with their own knowledges and experiences of farmed animal health science, either as trained veterinary surgeons, policy-makers or scientists. The thematic analysis (Braun and Clark, 2006) allowed us to identify commonalities and differences across transcripts and publications and, as the analysis progressed, more detailed codes emerged. From this detailed coding, theme analysis work, and comparison of written and oral materials we were able to strengthen our understanding of the science of CADM and hypothesise about the scientific logic of routine animal health care in industrial farming; a theme we turn to in the following section.

\section{Chronic animal diseases and the industrial logic of capital}

This section identifies the construction of a scientific logic of routine animal health care in industrial farming and sets out the three core components of our findings drawn from the joint analysis of the literature review and the interviews. First, we present the scientific research on CADM in industrial farming, its underlying scientific assumptions and shared definitions (Berger and Luckmann, 1966). Second, we illuminate how scientific discourse and practice emerge from particular forms of research, generated through scientific traditions, 'social interaction and socialisation' (Lupton, 2000, p. 51). Finally, we disentangle the hegemonic powers and tensions emerging from different visions of CADM among farmed animal health practitioners in Europe. Taken together, these components support Stengers's (2018) argument that the science of CADM in industrial farming is shaped-and dominated by-an industrial logic of 'fast sciences' (Stengers, 2018) for capitalist production and market operations, despite growing concern for public health inherent in farmed animal health and infectious diseases.
The currency of chronic animal diseases and their scientific management. The number of scientific publications related to chronic digestive and respiratory disease management in the large-scale industrial broiler, cattle, and pig production has increased since the 1980s (Fig. 1) - a period from which the adverse effects of industrial practices on farmed animal health and welfare begin to be visible in Europe and provoke ethical and scientific questions about the multiple drawbacks of the capitalist model of large-scale industrial animal production (Harrison, 1964; Flatrès and Flatrès, 1997; McCausland, 2014) — that is, a model 'organised primarily through the operation of markets' (Schrecker and Bambra, 2015, p. 8) and the 'rise of consumerism' (Lowe et al., 2008, p. 227).

Although interviewees agreed that chronic animal diseases are linked to industrial farming and intensive forms of animal husbandry, they explained, however, that this neither made them nor their management a subject of public health interest. Indeed, for our interviewees, the science of CADM remained informed and shaped by international market regimes rather than by public health innovations and policies-that is, 'business rumours', 'competition between industries' and 'political and industrial lobbying' [quotes from public sector AHS 6 and private sector AHS 9 and 11]. In publications, too, the science of CADM is not about improving animal welfare and reorienting practices of industrial farming. Rather, it is about preventing significant financial and economic pitfalls for the food industry (see for example, Williams, 1999; Nieuwenhuis et al., 2012; Györke et al., 2016). In fact, only 7 authors in our bibliometric sample (6\%) used the term 'welfare' to present their research and explain its value to the reader. Note also that in these publications, the term 'welfare' often comes after that of 'economic', ultimately subordinating it to food markets and international trading regimes' (Lowe et al., 2008, p. 227). As an example, Ter Veen et al. (2017) explain in the first sentence of their abstract and introduction: 'Intestinal disease has a major impact on the broiler industry due to economic and welfare reasons' (see Supplementary Material for the list of the scientific publications included in the analysis). As one public sector AHS [8, woman] clarified in interviews, animal welfare is just a 'plus' and the science of CADM primarily an investment, an 'economic practice' for industrial profit and sale:

'It is not to improve the health of farmed animals per se, but for industrial economic purposes [...] Diseases like coccidiosis have a direct impact on weight gain and feed conversion ratio. Then, [...] if [the industry] can show that they have animals in good health, and therefore, in good welfare, that's good.'

Broilers, in particular, have historically been the most intensively researched investment commodities of the food industry. Boyd (2001) notes that, in the US context, this led the food industry to create in-house research frameworks for 'rapidly translating research into commercial gain' (p. 632). In our study, half as many publications were identified for broilers $(N=18)$ than cattle $(N=53)$ and pigs $(N=47)$, suggesting that European broiler research is likely to be influenced strongly by private interests too. In fact, this was confirmed by our interviewees, especially one public sector AHS [8, woman], who critiqued the too frequent fads of private science and therapeutic solutions for CADM in broilers:

'Now microbiotics have become the fashionable thing in industrial broilers [...] it's gone into the commercial realm before we [AHS] even understand how it works and what the effects are.' 
Fig. 1 Distribution of scientific publications by species and disease between 1978 and $2017(\boldsymbol{N}=\mathbf{1 1 8})$. Publications on chronic digestive diseases in broilers are shown in yellow; on chronic respiratory diseases in cattle, in blue; and on chronic respiratory diseases in pigs, in pink.

Not perceived as having a direct impact on public health, the science of CADM does not, according to interviewees, attract public attention like so-called mad cow disease or bird flu-two important zoonoses particularly represented in the public sector (Buller and Morris, 2003; Keck, 2008). As one public sector AHS [6, woman] stated explicitly:

'The resources in place in the public sector are not huge [...] There is hardly anybody working at the European level on poultry digestive diseases [...] because it is not the priority.'

This was also apparent in the relative importance of publications on CADM according to diseases: only diseases with possible repercussions on human health (for example, bovine respiratory diseases which are important sources of antibiotic use) or the global economy (for example, $\mathrm{PRRS}^{1}$ ) could become a priority, attract public research funding and be more visible (Fig. 1). Hence, research on CADM, as practised and used by AHS, appears to support what Hamilton and Mitchell (2018) call a 'human form of rationality, and the mechanism of capital exchange' (p. 347) - both as an origin and a product of animal health extraction for science and the food industry, a currency exchange from animal health to humans; human health, yield and productivity.

Manufacturing the science of chronic animal disease management. Chronic animal diseases are 'old', 'have existed for a very long time' and have increased with farming industrialisation, 'intensification' and rising 'animal densities' [quotes from public sector AHS 3 and 5, private sector AHS 10, VS 4, and PM 3]. The reasons for their persistence are well known to all practitioners interviewed, regardless of their work as AHS, VS, and PM, and are entwined with neoliberal economics and politics of the food industry, 'which place markets at the centre of all economic and social life' (Schrecker and Bambra, 2015, p. 8). As one public sector AHS [1, woman] highlighted:

'We know that stressing and mixing animals provides excellent conditions for the explosion of respiratory diseases.'

For a PM in France [1, man], however, one of the reasons for the persistence of chronic animal diseases in industrial farming was science itself. For this interviewee, chronic animal diseases would never be entirely solved for they support science by creating research opportunities that science and AHS rely upon:

'[...] fundamental research on chronic animal diseases [...] feeds a lot of people. I would like to know how many scientists live on the back of farmed animal health science.'

As another VS [4, man] further commented, science and industrial animal production are connected through the language of 'reasonableness':

'[Farmers] [...] who have remained reasonable in the size of their farm do not need veterinary services because their herds are in good health.' 
Whether one regards the increasing importance of science-production interaction in industrial farming as an outcome of production intensification and animal ill-being or, conversely, as a function of an increasingly production-focused and more scientific approach to animal farming, in practical terms, CADM has become 'an element of support' (Foucault, 1984 , p. 253) for the dual-benefit of chronic animal health science and the food industry.

The interweaving of the science of CADM and the food industry had also the effect of shaping research practices for CADM in industrial farming. A public sector AHS [8, woman], for example, asserted that the science of CADM in industrial farming is compartmentalised, technical and mechanical by nature rather than holistic and driver of agricultural change, because this is how the science of CADM is funded, knowledge on CADM produced and published, and therefore, prioritised by AHS:

'For the moment, everyone goes for its own interests and research separately... vaccination, genetics, nutrition...'

Another [public sector AHS, 5, man] also explained how providing technical and simplified solutions, fast, standardised, and visible actions-targeted towards quick agricultural impact, production, and profit-is particularly attractive and appreciated by funders of research and the food industry:

'Eimeria tenella is a more promising [pathogen] for institutions that support researchers. [AHS] say: "I work on [parasites] we can see, so [funders] know they are the issue". They are also the easiest species to work [...] because they [...] make blood, they are easy to isolate and to purify.'

In all publications, diseases and pathogens were transformed and made visible through mechanistic, standardised and often unidisciplinary processes (such as Bayesian models, multilevel statistical models and molecular genetics). These highly technical approaches and tools turn invisible diseases into tangible quantities. They describe biological processes, reveal 'responsible pathogens' (a term frequently used in publications) and advocate for particular and lucrative industrial options such as drugs and vaccines (as in $81 \%$ of the publications). Tangible, rapid and lucrative 'cures' are not only a scientific goal but an aspiration, not only for the technological (and economic) development of the food and pharmaceutical industry but also for AHS and their research institutions:

'I had a dream, to find an analysis where one can sample a piece of meat and tell you there was good animal welfare [...] that, would be an economic success.' [public sector AHS 6, man]

Through their scientific choices and practice, AHS translate complex and invisible pathological processes into simple, tangible, lucrative and desirable ones. As Lupton (2000) argues, science interact[s] in producing and reproducing the discourses and practices and, thus, the meanings and experiences of health, illness and medical care' (p. 53). Rather than disrupt the structures and dynamics of industrial animal production and, ultimately, their interactions with the food and pharmaceutical industry, AHS promote a science of CADM supported by technological advances and industrial development. AHS sometimes critiqued excessive production demands, but often attributed it to a need to balance discourses of human and farmed animal needs. They also appeared to struggle within their own community under increased pressure from a more generalised scientific logic of 'industrialisation and managerialization' within the life sciences (Latimer, 2019, p. 264).
Between scientific ideals and the practice of routine animal health care in industrial farming. Constrained by research funding, peer-review, scientific silos and research methodologies, the science of CADM does not, according to many farmed animal health practitioners, have sufficient means to explore the broader determinants 'constituting', in Hinchliffe's words (2015), animal ill- and well-being in industrial farming. As one public sector AHS [6, man] explained, the silent nature of chronic animal diseases and the scientific technical apparatus further support a very industrial and profit-oriented rationale for the production of scientific knowledge on CADM:

'Seeing an animal that has subclinical problems, you're not going to see it from the outside. Growth problems will be seen through animals' productivity, not through their appearance.'

In a professional sense, AHS, VS, and PM all felt 'ethically responsible for the prevention and the reduction of diseases that make animals suffer' [public sector AHS, 8]. However, they explained their difficulty in resisting and responding to competing structures and expectations of what it means to scientifically care for CADM. The call for a ban on the use of antibiotics in industrial farming encouraged by AHS, public health authorities and wary consumers, for example, represented for many VS professional irresponsibility, the mistreatment of farmed animals. As this French VS [1, man] explained:

'Animal disease, nobody cares. If a cow dies, [public health authorities] don't care. We are not allowed to use this or that product $[\ldots]$ if this means that the animal dies, that's ok because it is planned in the regulation.'

Participants often attributed these 'tensions' (Law, 2010) between scientific advice, farmed animal health policies and veterinary practice to a nascent but increasing social divide between different backgrounds and expertise, practices and ethical values, often intersecting different human-animal and human-environmental relations. As two interviewees suggested:

'If there is one community detached from the field, where egos are oversized, it is that of AHS. I have known them closely. AHS should be at the service of people, purposes, things, but not themselves.' [PM 3, man]

'PM no longer have any notion of pathologies [...] They give authorisations for the construction of animal barns which are cathedrals, completely incompatible with good air circulation, good management, and animal well-being' [French VS 1, man]

Whatever their disagreements, however, all practitioners agreed on the need to revise the scientific purposes of CADM in industrial farming; to move beyond a scientific logic of routine animal health care for grant money, professional security, and industrial output. Interviewees comprehend the need to 'work holistically' and to promote a new 'sociality', in Latimer's term (2013), between humans and farmed animals that could help build a new scientific logic of routine animal health care in industrial farming-one that could benefit both the animal and animal husbandry. They explained how there was a need to reorientate research on CADM, to find new trajectories to make farmed animal health 'matter' (Moser, 2008), but recognised internal and external vectors at play which prevented them from voicing these convictions and acting upon them:

'You need courage to [speak out] [...] this has always been the case with people who know. You are afraid of people who know [...] if you denounce them, you are judged, you 
are burnt alive because it is a corporation. VS, AHS, medical doctors are corporatists, and someone who will say: "you are too corporatist" will be excluded from the community, it will be finished, no more career, nothing [...] Why isn't anybody doing it? Because it's very comfortable. The corporatism of animal science exists and it works hand in hand with the pharmaceutical industry.' PM [3, man]

'We do not value intellectual input, so it's always the sale of [a drug or a vaccine] that will pay for our [scientific] activities' [French VS 2, man]

As these two comments illustrate, the science of CADM is tied to, and under the control of, professional and social structures and orders. The socialisation of the science of CADM as an economic and industrial practice not only structures the way in which scientific knowledge is produced, but also how animal health practitioners (be they AHS, VS, or PM) are educated, have to practice and work for hand in hand with the pharmaceutical and the food industry. This matter was stressed by our interviewees:

'When I started [at the veterinary school], I was offered a stethoscope and my year was named after a big pharmaceutical company.' [French PM, 3]

'Some veterinary schools do services for pharmaceutical companies to test things [...] We actually do these services and if we are asked not to publish the results because they are not up to the expectation of our industrial partner we will not have the right to publish.' [public sector AHS, 1]

'VS have remained until recently too focused on prescribing [...] I am not sure they were able to seize the opportunity of the demedicalisation of animal farming and explore that of animal welfare, because they mainly saw their loss of profits related to antibiotics.' [private sector AHS, 10]

Exploring the science of CADM in industrial farming enables us to re-think the scientific logic of routine animal health care in industrial farming not solely as a technical and economic process of capital-output but as a practice of care in which powerrelations are produced and affirmed between species, communities of practitioners, and the food and pharmaceutical industry. Our findings show that the science of CADM in industrial farming is subject to capitalist and human-centered motivations that feed consumerism and contribute to the intensification of animal husbandry at the risk of 'precipitating cycles of economy and disease' (Wallace et al., 2015, p. 69). The scientific logic of routine animal health care in industrial farming is also inconsistent with a more-than-human 'solidarity as ethical practice in public health research' (Rock and Degeling, 2015, p. 63) and sine qua non of One Health (Friese and Nuyts, 2017). This finding has significant ramifications for the way that farmed animal health science is organised, perceived and might evolve to reorientate research practices towards ethical responsibilities and we turn to this in greater detail in the following discussion.

\section{Discussion}

Because the science of CADM is locked into specific social and institutional spaces, routine animal health care in industrial farming may be diverted, in Foucault's terms (Foucault, 1984), from the 'good intentions' (p. 245) of liberating animals from illbeing and caring for their health and well-being. This, we argue, has the negative effects of supporting-rather than eliminating- the emergence and re-emergence of animal diseases and pathogens in industrial farming.

AHS must, for their own professional survival, show the economic value of their research to their investors and 'clients', primarily the pharmaceutical and food industries where chronic animal diseases appear not to be an urgent public health priority. Woods (2014) rightly argues that 'productivist agricultural agendas' and the 'practicalities of scientific investigation moulded the conduct of [farmed animal health] research and its effects on production' (p. 294). Supporting that argument, our research highlights that the public invisibility of research on CADM contributes to a situation in which routine animal health care and veterinary services in industrial farming function as technical support for agriculture, but stifling potential innovations that could lead to the resolution of chronic animal health conditions. Food and pharmaceutical companies, through their industrial strategies, models and everyday practices, are precipitating and reproducing these conditions by seeking a narrow view of 'useful' knowledge and technical skills.

This problematic situation has (inadvertently) facilitated many public health crises such as AMR and bird flu (Wallace, 2009; Kirchhelle, 2018) which Schrecker and Bambra (2015) could rightly link to social construction of scientific practice in which 'neoliberal epidemics' flourish. Many scientists are at pains to resist the 'discomfort' that arises from such a charge but remain tethered, nonetheless, to historic links to the food industry and its commercial impulses. Rather than making chronic animal disease a burning public health issue, the science of CADM has become a linchpin tool within meat and dairy markets, the cornerstone of private (and mostly deregulated) biosecurity and disease control (see for example, Lowe, 2009; Hinchliffe et al., 2013), overseers of supply routes which are central to farm strategy and commercial planning. As such, the science of CADM works within and helps shape, a neoliberal and economic-rational code of industrial practice in animal husbandry (Enticott et al., 2011) that articulates the goals of pharmaceutical producers, governments, venture capitalists, supermarkets and other powerful actors. While, as Lowe (2009) has pointed out, there are contradictions, paradoxes and complications in the relationship between science, veterinary practice and commercial providers of various types, and it would be a mistake to reduce this to a model of cynical capital exchange, our research highlights that there is-nonetheless-a close linkage between consumerism, commercial rationality, and routine animal health care in industrial farming which has produced a formal order of research and systematic scientific logic of CADM comparable to the organisation of work in industrial systems of agricultural production (Ikerd, 2011; Godley, 2014).

Such productivist agendas, historically embedded in a professional 'military discipline' (Foucault, 1984), means that the science of CADM has been socially engineered as a series of actions on parts rather than the 'full body'. It has focused on machines and biological processes rather than social relations and entire living beings. As the founder of the first veterinary school once stated (Bourgelat, 1762; Bourgelat, 1777), the science of farmed animal health consists of scientific 'brigades' (Bourgelat, 1777) 'keep[ing] the parts of the machine in their integrity and [...] repair[ing] its disorders and alterations' (Bourgelat, 1762). Our study shows how the science of CADM remains largely compartmentalised, specialised and simplified in different units of knowledge production such as immunology, genetics and nutrition. While compartmentalisation produces some efficiencies through specialisation, as Ikerd (2011) argues, this 'allows consolidation of control into large-scale, corporate business enterprises' (p. 2) and boxes the industrial rationale of the science of CADM and routine animal health care in industrial farming into a 'smaller epistemic corner' (Heintzman, 2018, p. 258) which fails 
to recognise all the health and well-being needs of farmed animals (Bennett et al., 2000; Porcher and Schmitt, 2012) and the capacity of diseased animals to harbour and spread pathogens. In its lack of attention to chronic animal disease, the science of CADM has inadvertently fostered the resilience and adaptation of a host of pathogens to large-scale industrial production. As veterinary literature shows (Anderson, 2008; Kasonta et al., 2012), the scientific logic of control (Hinchliffe et al., 2013) rather than care, can serve (paradoxically) as the source of public health problems and pandemics (Law, 2010; Blue and Rock, 2011; Rock and Degeling, 2015) as the recent crisis of antibiotic resistance has demonstrated (Bellet, 2018).

Today, the practice of farmed animal health management looks rather different from its historical antecedents. Many of those we interviewed were keen to distance themselves from the capitalist logic of CADM but also recognised the intractable nature of the relationships between commerce and science. The science of CADM, funded by and working in tandem with the food industry, has problematised its capacity to adapt to a new social contract of care orientated towards a less human-centered farmed animal health (Buller and Morris, 2003) despite a proliferation of increasingly vocal consumer perceptions about the source and ethics of food (Mol, 2009). We must not reduce this knotty social and economic problem to an animal health practitioner issue because academic enquiries in animal health and healthy forms of animal husbandry are intertwined (Porcher, 2014) with multiple stakeholders, each with their own agendas which are often contradictory in nature.

We, however, view the science of CADM as part of a broader realm of animal health, welfare, and care in industrial farming, which involves learning to attend more closely to (Porcher, 2014) farmed animal ill- and well-being; to make chronic diseases a priority despite their lack of public health standing. Our research has highlighted the difficulty of pursuing this agenda in a European context where the science of CADM remains 'socially cast' (Buller and Morris, 2003) as an endeavour for humans, their consumption and profit. Blockages to innovation and research also emerge from the lack of collaboration between different branches of science and even within their own community-some farmed animal health experts have more social capital than others depending on the 'utility' (Timotijevic et al., 2019, p. 2) of their practice for economic growth and profit-making policies. On this basis, we argue that the science of CADM could be depicted as being 'under siege' (Latimer, 2019; Wade, 2021) from the complex, and sometimes contradictory, pressures of economic growth which Stengers (2018) describes as a frenetic state. New scholarship (Cassidy, 2017; Gorman, 2019; Kirk et al., 2018; Davies et al., 2020) has begun to offer a valuable vision of the meaning of human-animal relationships, 'connections' (Latimer, 2013) and interspecies care in public health and One Health, although some of this work stems from the inclusion of animals in the search of human health. Like many of our interviewees, however, we believe that animal health is, in its own right, of intrinsic interest to public health and One Health knowledge. Understanding it holistically, within social as well as scientific context, carries the potential for significant benefits as we seek to dwell and thrive amidst different kinds' (Latimer, 2013).

\section{Conclusions}

To conclude, this study has provided new empirical perspectives on the social construction of routine animal health care in industrial farming and public health, the link between the health of farmed animals and our health and how this is vital for understanding our responses to public health crises such as AMR and pandemics. Our findings show that human interests dominate the science of routine animal health care and leave the door open to serious public health crises (Dingwall et al., 2012). Research and development on CADM have yet to capture the attention of public health policy-makers and some consumers (Verbeke and Viaene, 2000; Porcher and Schmitt, 2012). We have sought to explain this by drawing attention to the competitive and capitalist drivers of the food and pharmaceutical industries which take a strong role in setting agendas for academic enquiry. Scientists and veterinary practitioners may, at times, seek to appear resistant to this logic but our research demonstrates its continued potency as a blockage to change. This is problematic for those who have the social, scientific and technical capital to broker realistic and lasting legacies in animal husbandry for public health. The significant obstacles in the way science is funded, organised and put into practice continue to militate against change.

In the complex multiplicity of interests surrounding agriculture (Lowe, 2009), new strategies for developing the science of CADM could drive and shape a new culture of routine animal health care 'from within' (Hinchliffe et al., 2013) by demonstrating the importance of everyday farmed animal health and well-being for public health. As the recent pandemic has shown, the interaction between human and animal health is less distant than many have previously assumed. There is a need to value the health and chronic health conditions of animals as 'voices' (Despret, 2016; Hamilton and Taylor, 2017) in the order of public health knowledge to prioritise a less human-centered view of health, science and agricultural production and consumption. This is essential because if different interests are to be acknowledged (Rock et al., 2014), human 'experts' need to embrace and work with the interconnected, rather than competing, interests of human and animal lives. Given that it is our own species that speaks about and for animals in agriculture and science, the recognition of farmed animal daily health means taking account of a variety of animal spokespeople and increasing dialogue across the range of disciplinary boundaries. It is this paradigm shift that will prepare us for, and build resilience to, new disease outbreaks which threaten to disrupt the fabric of our societies.

\section{Data availability}

All data generated or analysed during this study are included in this published article.

Received: 3 November 2020; Accepted: 19 August 2021; Published online: 20 September 2021

\section{Note}

1 Economic impact in the swine industry. Available at: https://www.prrscontrol.com/ prrs-the-disease/economic-impact-in-swine-industry/

\section{References}

Al Hajjar S, Memish ZA, McIntosh K (2013) Middle East Respiratory Syndrome Coronavirus (MERS-CoV): a perpetual challenge. Ann Saudi Med. 33(5):427-436. https://doi.org/10.5144/0256-4947.2013.427

Allen T, Murray KA, Zambrana-Torrelio C, Morse SS, Rondinini C, Di Marco M, Breit N, Olival KJ, Daszak P (2017) Global hotspots and correlates of emerging zoonotic diseases. Nat Commun 8:1124. https://doi.org/10.1038/ s41467-017-00923-8

Andersen KG, Rambaut A, Lipkin WI, Holmes EC, Garry RF (2020) The proximal origin of SARS-CoV-2. Nat Commun 26:450-452. https://doi.org/10.1038/ s41591-020-0820-9

Anderson I (2008) Foot and mouth disease 2007: review and lessons learned. In: T.H.O. (Ed) Commons. The Stationery Office, London

Andrews GJ, Duff C (2019) Matter beginning to matter: on posthumanist understandings of the vital emergence of health. Soc Sci Med 226:123-134. https:// doi.org/10.1016/j.socscimed.2019.02.045 
Anonymous (2015) New analysis of pig disease costs. Pig World. http://www.pigworld.co.uk/news/business/new-analysis-of-pig-disease-costs.html. Last modified November 11

Barroux G (2011) La santé des animaux et l'émergence de la médecine vétérinaire au XVIIIe siècle. Rev Hist Sci 2(64):349-376

Bastide F (1990) The iconography of scientific texts: principles of analysis. In: Lynch Michael E, Steve W (eds) Representation in scientific practice. The MIT Press, USA/UK, pp. 187-230

Bellet C (2018) Change it or Change it or perish? Drug resistance and the dynamics of livestock farm practices. J Rur Stud 63:57-64. https://doi.org/10.1016/ j.jrurstud.2018.08.016

Bennett R, Henson S, Harper G, Blaney R, Preibisch K (2000) Economic evaluation of farm animal welfare policy: baseline study and framework development. Report to the Ministry of Agriculture, Fisheries and Food. The University of Reading, UK

Berdah D (2010) La vaccination des bovidés contre la tuberculose en France, 1921-1963: entre modèle épistémique et alternative à l'abattage. Rev Agric Environ Stud-Rev Etud Agric Environ (RAEStud) Inst Natl Rech Agron (INRA) 91:393-415

Berger PL, Luckmann T (1966) The social construction of reality-a treatise in the sociology of knowledge. Penguin Books, USA

Blue G, Rock M (2011) Trans-biopolitics: complexity in interspecies relations. Health 15:353-368. https://doi.org/10.1177/1363459310376299

Bonnaud L, Fortané N (2016) Au-delà des crises de santé animale Pour une sociologie de l'action publique vétérinaire. Gouv action publique 3(5):131-140

Bonnaud L, Fortané N (2020) Being a vet: the veterinary profession in social science research. Rev Agric Food Environ Stud. https://doi.org/10.1007/ s41130-020-00103-1

Bourgelat C (1762) op. cit. In Journal encyclopédique, Tome 1. Premiere partie, n. 37, 7. l'Imprimerie du Journal, France

Bourgelat C (1777) Règlements pour les Écoles royales vétérinaires de France. l'Imprimerie du Journal, France

Boyd W (2001) Making meat science, technology, and American poultry production. Technol Cult 42(4):631-664. https://www.jstor.org/stable/25147798

Braun V, Clark V (2006) Using thematic analysis in psychology. Qual Res Psychol 3(2):77-101

Brockmeier SL, Halbur PG, Thacker EL (2002) Porcine respiratory disease complex. In:Brogden KA, Guthmiller JM (eds) Polymicrobial diseases. ASM Press, Washington

Brown H, Nading AM (2019) Introduction: human animal health in medical anthropology. Med Anthropol Q 33(1):5-23. https://doi.org/10.1111/ maq. 12488

Buller H, Morris C (2003) Farm animal welfare: a new repertoire of nature-society relations or modernism re-embedded? Sociol Ruralis 43(3):216-237. https:// doi.org/10.1111/1467-9523.00242

Cassidy A (2017) Humans, other animals and 'one health' in the early twenty-first century. In: Carsten T, Michael W (eds) Animals and the shaping of modern medicine. One health and its histories. Palgrave Macmillan, Switzerland, pp. $193-236$

Charmaz K (2009) Shifting the grounds: constructivist grounded theory methods for the twenty-first century. In: Morse Janice M, Barbara B, Kathy C, Clarke Adele E, Juliet C, Noerager SP (eds) Developing grounded theory-the second generation. Routledge Taylor \& Francis Group, London \& New York

Cherry JD, Krogstad P (2004) SARS: the first pandemic of the 21st century. Pediatr Res 56(1):1-5. https://doi.org/10.1203/01.PDR.0000129184.87042.FC

Christianson WT, Joo H (1994) Porcine reproductive and respiratory syndrome: a review. Swine Health Prod 2:10-28

Conly JM, Johnston BL (2004) Avian influenza-the next pandemic? Can J Infect Dis Med Microbiol 15(5):252-254. https://doi.org/10.1155/2004/121394

Davies G et al. (2020) Animal research nexus: a new approach to the connections between science, health and animal welfare. Med Hum. https://doi.org/ 10.1136/medhum-2019-011778

Despret V (2016) What would animals say if we asked the right questions? Press Minneapolis, London

Dingwall R, Hoffman LM, Staniland K (2012) Introduction: why a sociology of pandemics? Sociol Health Illn 35(2):167-173. https://doi.org/10.1111/14679566.12019

Enticott G, Donaldson A, Lowe P, Power M, Proctor A, Wilkinson K (2011) The changing role of veterinary expertise in the food chain. Philos Trans R Soc Lond B Biol Sci 366(1573):1955-1965. https://doi.org/10.1098/rstb.2010.0408

Enticott G, Ward K (2020) Mapping careful epidemiology: spatialities, materialities, and subjectivities in the management of animal disease. Geog J 186(3):1-12. https://doi.org/10.1111/geoj.12341

Eurostat (2020a) Bovine population-annual data. Live bovine animals. European Commission, Belgium, https://appsso.eurostat.ec.europa.eu/nui/ show.do?dataset=apro_mt_lscatl\&lang=en. Accessed 2 Oct 2020
Eurostat (2020b) Pig population-annual data. Live swine, domestic species European Commission, Belgium, http://appsso.eurostat.ec.europa.eu/nui/ show.do?dataset=apro_mt_lspig\&lang=en. Accessed 2 Oct 2020

Eurostat (2020c) Poultry-annual data. Chicks of meat broiler breeds (fattening) European Commission, Belgium, https://appsso.eurostat.ec.europa.eu/nui/ show.do?dataset=apro_ec_poula\&lang=en. Accessed 2 Oct 2020

Fairclough N (1992) Discourse and social change. Polity Press, UK

Farley MM (2010) 2009 H1N1 influenza: a twenty-first century pandemic with roots in the early twentieth century. Am J Med Sci 340(3):202-208. https:// doi.org/10.1097/MAJ.0b013e3181e937b0

Flatrès $H$, Flatrès $\mathrm{P}$ (1997) Mutations agricoles et transformations des paysages en Europe. In: Norois (ed), Crises et mutations agricoles et rurales. Norois, France, pp. 173-193

Fortané N (2020) Antimicrobial resistance: preventive approaches to the rescue? Professional expertise and business model of French "industrial" veterinarians. Rev Agric Food Environ Stud. https://doi.org/10.1007/s41130-01900098-4

Foucault M (1975) The birth of the clinic: an archeology of medical perception Vintage Books, USA

Foucault M (1984) The foucault reader. Pantheon Books, USA

Foucault M (1989) The order of things: archaeology of the human sciences. Routledge, UK

Friese C, Nuyts N (2017) Posthumanist critique and human health: how nonhumans (could) figure in public health research. Crit Public Health 27(3):303-313. https://doi.org/10.1080/09581596.2017.1294246

Godley A (2014) The emergence of agribusiness in Europe and the development of the Western European broiler chicken industry, 1945 to 1973. AgHR 62(2):315-336

Gorman R (2019) Thinking critically about health and human-animal relations: therapeutic affect within spaces of care farming. Soc Sci Med 231:6-12

Gubler DJ (2007) The continuing spread of West Nile virus in the western hemisphere. Clin Infect Dis 45(8):1039-1046. https://doi.org/10.1086/521911

Györke A, Kalmár Z, Pop LM, Loan Şuteu O (2016) The economic impact of infection with Eimeria spp. in broiler farms from Romania. Rev Bras Zootec 45(5):273-280. https://doi.org/10.1590/S1806-92902016000500010.

Hamilton L, Taylor N (2017) Ethnography after humanism: power, politics and method in multi-species research. Palgrave macmillan, UK

Hamilton L, Mitchell L (2018) Knocking on the door of human-animal studies: valuing work across disciplinary and species borderlines. Soc Anim 26(5):347-366

Harrison R (1964) Animal machines. Vincent Stuart Publishers Ltd, UK.

Heintzman K (2018) A cabinet of the ordinary: domesticating veterinary education. BSHS 51(2):239-260. https://doi.org/10.1017/S0007087418000274

Hinchliffe S, Allen J, Lavau S, Bingham N, Carter S (2013) Biosecurity and the topologies of infected life: from borderlines to borderlands. Trans Inst $\mathrm{Br}$ Geogr 38(4):531-543. https://doi.org/10.1111/j.1475-5661.2012.00538.x

Hinchliffe S (2015) More than one world, more than one health: re-configuring interspecies health. Soc Sci Med 129:28-35. https://doi.org/10.1016/ j.socscimed.2014.07.007

Husu-Kallio J (2008) Animal health and animal welfare-is it the same thing? Acta Vet Scand 50(S2). https://doi.org/10.1186/1751-0147-50-S1-S2

Ikerd J (2011) Agriculture in the post-industrial era-challenges and opportunities for Alaskans. Workshop on sustainable livestock production, National Institute of Food and Agriculture, Alaska. Anchorage, Alaska

Jones PJ, Niemi J, Christensen JP, Tranter RB, Bennett RM (2019) A review of the financial impact of production diseases in poultry production systems. Anim Prod Sci 59(9):1585-1597. https://doi.org/10.1071/AN18281

Kaner J, Schaack S (2016) Understanding Ebola: the 2014 epidemic. Glob Health 12(53). https://doi.org/10.1186/s12992-016-0194-4

Kasonta R, Sauter-Louis C, Holsteg M, Duchow K, Cussler K, Bastian M (2012) Effect of the vaccination scheme on PregSure BVD induced alloreactivity and the incidence of Bovine Neonatal Pancytopenia. Vaccine 30(47):6649-6655. https://doi.org/10.1016/j.vaccine.2012.08.069

Keck F (2008) From mad cow disease to bird flu. Transformations of food safety in France. In: Lakoff Andrew, Collier StephenJ eda Biosecurity interventions. Global health and security in question. Columbia University Press, USA

Kirchhelle C (2018) Pharming animals: a global history of antibiotics in food production (1935-2017). Palgrave Commun 4(1):96. https://doi.org/10.1057/ s41599-018-0152-2

Kirk RGW, Pemberton N, Quick T (2018) Being well together? Promoting health and wellbeing through more than human collaboration and companionship. Med Humanit 45(1):75-81. https://doi.org/10.1136/medhum-2018-011601

Lashley FR (2006) Emerging infectious diseases at the beginning of the 21st century. Online J Issues Nurs 11(1):2

Latimer J (2013) Being alongside: rethinking relations amongst different kinds. Theory Cult Soc 30(7-8):77-104. https://doi.org/10.1177/0263276413500078 
Latimer J (2019) Science under siege? Being alongside the life sciences, giving science life. Sociol Rev 67(2):264-286. https://doi.org/10.1177/ 0038026119829752

Law J (2010) Care and killing: tensions in veterinary practice. In: Mol Annemarie, Moser Ingunn, Pols Jeanette (eds) Care in practice: on tinkering in clinics, homes and farms. Transcript Publishers, Germany, pp. 57-72

Lawrence F (2016) If consumers knew how farmed chickens were raised, they might never eat their meat again-the debate about animal welfare has intensified. The Guardian. https://www.theguardian.com/environment/2016/ apr/24/real-cost-of-roast-chicken-animal-welfare-farms

LeBoeuf A (2011) Making sense of one health-cooperating at the human-animal-ecosystem health interface. Health Environ Reports. IFRI, France

LePan N (2020) Visualizing the history of pandemics. Visual Capitalist. https:// www.visualcapitalist.com/history-of-pandemics-deadliest/

Lowe P, Phillipson J, Lee RP (2008) Socio-technical innovation for sustainable food chains: roles for social science. Trends Food Sci Technol 19:226-233

Lowe P (2009). Unlocking Potential-a report on veterinary expertise in food animal production. https://www.vetfutures.org.uk/resource/unlockingpotential-a-report-on-veterinary-expertise-in-food-animal-production-2009/

Lupton D (1994) Medicine as culture: illness, disease and the body in western societies. SAGE Publications Ltd, UK

Lupton D (2000) The social construction of medicine and the body. In: Albrecht Gary L, Fitzpatrick Ray, Scrimshaw Susan C (eds) Handbook of social studies in health and medicine. SAGE Publications Ltd, UK, pp. 50-63

McCausland C (2014) The five freedoms of animal welfare are rights. J Agric Environ Eth 27(4):649-662. https://doi.org/10.1007/s10806-013-9483-6

Mitsuda T (2017) Entangled histories: German veterinary medicine, c.1770-1900. Med Hist 61(1):25-47. https://doi.org/10.1017/mdh.2016.99

Mol A (2008) The logic of care: health and the problem of patient choice. Routledge, UK

Mol A (2009) GOOD TASTE. The embodied normativity of the consumer-citizen. J Cult Econom 2(3):269-283. https://doi.org/10.1080/17530350903345504

Mol A, Moser I, Pols J (2010) Care: putting practice into theory. In: Mol Annemarie, Moser Ingunn, Pols Jeanette (eds) Care in practice: on tinkering in clinics, homes and farms. Transcript Publishers, Germany, pp. 7-26

Moser I (2008) Making Alzheimer's disease matter: enacting, interfering, doing politics of nature. Geoforum 39(1):98-110. https://doi.org/10.1016/ j.geoforum.2006.12.007

Nicholas RAJ, Ayling RD (2003) Mycoplasma bovis: disease, diagnosis, and control. Res Vet Sci 74(2):105-112. https://doi.org/10.1016/s0034-5288(02) 00155-8

Nieuwenhuis N, Duinhof TF, van Nes A (2012) Economic analysis of outbreaks of porcine reproductive and respiratory syndrome virus in nine sow herds. Vet Rec 170(9):225. https://doi.org/10.1136/vr.100101

Nir O (2003) What are production diseases, and how do we manage them? Acta Vet Scand 44(P1):S21. https://doi.org/10.1186/1751-0147-44-S1-P1

Peek SF, Ollivett TL, Divers TJ (2017) Respiratory diseases. In: Peek SF, Divers TJ eds Rebhun's diseases of dairy cattle. Elsevier, USA

Pickersgill M, Chan S, Haddow G, Laurie G, Sridhar D, Sturdy S, CunninghamBurley S (2018) The social sciences, humanities, and health. Lancet 391(10129):1462-1463. https://doi.org/10.1016/S0140-6736(18)30669-X

Pike BL, Saylors KE, Fair JN, LeBreton M, Tamoufe U, Djoko CF, Rimoin AW, Wolfe ND (2010) The origin and prevention of pandemics. Clin Infect Dis 50(12):1636-1640. https://doi.org/10.1086/652860

Porcher J, Schmitt T (2012) Dairy cows: workers in the shadows? Soc Anim 20(1):39-60

Porcher J (2014) Vivre avec les animaux. Une utopie pour le XXIe siècle. La Découverte Paris, France

Robinson TP, Wint GRW, Conchedda G, Van Boeckel TP, Ercoli V, Palamara E, Cinardi G, D'Aietti L, Hay SI, Gilbert M (2014) Mapping the global distribution of livestock. PLoS ONE 9:e96084. https://doi.org/10.1371/ journal.pone.0096084

Rock MJ, Degeling C, Blue G (2014) Toward stronger theory in critical public health: insights from debates surrounding posthumanism. Crit Public Health 24(3):337-348. https://doi.org/10.1080/09581596.2013.827325

Rock MJ, Degeling C (2015) Public health ethics and more-than-human solidarity. Soc Sci Med 129:61-67. https://doi.org/10.1016/j.socscimed.2014.05.050

Roger F, Delabouglise A, Roche B, Peyre M, Chevalier V (2021). Origin of the Covid-19 virus: the trail of mink farming. The Conversation. https:// theconversation.com/origin-of-the-covid-19-virus-the-trail-of-minkfarming-155989

Rowan TG, Sunderland SJ, Smith DG, Sarasola P, Giles CJ (2004) Efficacy of danofloxacin in the treatment of respiratory disease in European cattle. Vet Rec 154(19):585-589. https://doi.org/10.1136/vr.154.19.585

Rushton J et al. (2018) Initiation of global burden of animal diseases programme. Lancet 392(10147):538-540. https://doi.org/10.1016/S0140-6736(18)31472-7
SAPHIR (2020) Strengthening animal production and health through the immune response. European Commission H2020 Project. https://cordis.europa.eu/ project/id/633184, Accessed 2 Oct 2020

Schrecker T, Bambra C (2015) How politics makes us sick. Neoliberal epidemics. Palgrave Macmillan, UK

Spinney L (2020) Is factory farming to blame for coronavirus? The Guardian https://www.theguardian.com/world/2020/mar/28/is-factory-farming-toblame-for-coronavirus

Standaert M (2020) Coronavirus closures reveal vast scale of China's secretive wildlife farm industry. The Guardian. https://www.theguardian.com/ environment/2020/feb/25/coronavirus-closures-reveal-vast-scale-of-chinassecretive-wildlife-farm-industry

Stengers I (2018) Another science is possible - manifesto for slow science. Polity Press, UK, p. 2018

Ter Veen C, de Bruijn ND, Dijkman R, de Wit JJ (2017) Prevalence of histopathological intestinal lesions andenteric pathogens in Dutch commercial broilers with time. Avian Pathol 46:95-105

Timotijevic L, Khan SS, Raats M, Braun S (2019) Research priority setting in food and health domain: European stakeholder beliefs about legitimacy criteria and processes. Food Pol 83:116-124. https://doi.org/10.1016/j.foodpol.2018.12.005

Tomley FM, Shirley MW (2009) Livestock infectious diseases and zoonoses. Philos Trans R Soc Lond B Biol Sci 364(1530):2637-2642. https://doi.org/10.1098/ rstb.2009.0133

Troncoso A (2016) Zika threatens to become a huge worldwide pandemic. J Trop Biomed 6(6):520-527. https://doi.org/10.1016/j.apjtb.2016.04.004

Verbeke WAJ, Viaene J (2000) Ethical challenges for livestock production: meeting consumer concerns about meat safety and animal welfare. J Agric Environ Eth 12:141-151. https://doi.org/10.1023/A:1009538613588

Villarreal I, Vranckx K, Duchateau L, Pasmans F, Haesebrouck F, Jensen JC, Nanjiani IA, Maes D (2010) Early Mycoplasma hyopneumoniae infections in European suckling pigs in herds with respiratory problems: detectionrate and risk factors. Vet med 55:318-324

Wade, N (2021) The origin of COVID: did people or nature open Pandora's box at Wuhan? Bull At Sci. https://thebulletin.org/2021/05/the-origin-of-covid-didpeople-or-nature-open-pandoras-box-at-wuhan

Wadiwel D (2015) The war against animals. Brill, The Netherlands

Wallace RG (2009) Breeding influenza: the political virology of offshore farming. Antipode

Wallace RG, Bergmann L, Kock R, Gilbert M, Hogerwerf L, Wallace R, Holmberg M (2015) The dawn of Structural One Health: a new science tracking disease emergence along circuits of capital. Soc Sci Med 129:68-77. https://doi.org/ 10.1016/j.socscimed.2014.09.047

Wallace R, Wallace RG (2015) Blowback: new formal perspectives on agriculturally driven pathogen evolution and spread. Epidemiol Infect 143:2068-2080. https://doi.org/10.1017/S0950268814000077

Wallace RG (2016) Big farms make big flu: dispatches on influenza. Agribusiness, and the Nature of Science. Monthly Review Press, USA

WHO (2020) Novel coronavirus (COVID-19) situation Coronavirus disease 2019 WHO. https://covid19.who.int/. Accessed 2 Oct 2020

Williams RB (1999) A compartmentalised model for the estimation of the cost of coccidiosis to the world's chicken production industry. Int J Parasitol 29(8):1209-1229. https://doi.org/10.1016/s0020-7519(99)00086-7

Woods A (2013) From practical men to scientific experts: British veterinary surgeons and the development of government scientific expertise, c. 1878-1919. Hist Sci 51:457-480. https://doi.org/10.1177/007327531305100404

Woods A (2014) Science, disease and dairy production in Britain, c.1927 to 1980 AgHR 62(2): 294-314. https://www.jstor.org/stable/43697982

Woods A (2019) Decentring antibiotics UK responses to the diseases of intensive pig production, c1925-65Z. Palgrave Commun 5(41). https://doi.org/10.1057/ s41599-019-0246-5

Yegani M, Korver DR (2008) Factors affecting intestinal health in poultry. Poult Sci 87(10):2052-2063. https://doi.org/10.3382/ps.2008-00091

\section{Acknowledgements}

$\mathrm{CB}$ currently receives funding from the Wellcome Trust as part of her Wellcome Trust Research Fellowship in Humanities and Social Science [219799/Z/19/Z] and is hugely grateful for Wellcome's ongoing support. The fieldwork of this research has received financial support from the European Union's Horizon 2020 Programme for research technological development, and demonstration [633184]. The authors would like to thank all the participants for their collaboration; Isabelle Schwartz-Cornil, Marie-Hélène Pinard-van der Laan, Jean-François Valarcher, Didier Raboisson and Jean-Christophe Audonnet for their help in recruiting participants; Lucie Fornili for supporting data collection; Bernadette Mallon for transcribing interviews; Barbara Ribeiro for providing critical comments on an earlier draft of this manuscript; and the anonymous peer reviewers for their insightful feedback. 


\section{Author contributions}

The corresponding author, $\mathrm{CB}$, led on the framing, fieldwork, analysis, and conception of the article; co-author LH made critical contributions to the conception of the article, helped revise it for important intellectual content; co-author JR obtained the grant to support fieldwork. All authors approved the version to be published and agreed to be accountable for its content.

\section{Competing interests}

The authors declare no competing interests.

\section{Additional information}

Supplementary information The online version contains supplementary material available at https://doi.org/10.1057/s41599-021-00890-y.

Correspondence and requests for materials should be addressed to Camille Bellet.

Reprints and permission information is available at http://www.nature.com/reprints
Publisher's note Springer Nature remains neutral with regard to jurisdictional claims in published maps and institutional affiliations.

(c) (i)

Open Access This article is licensed under a Creative Commons Attribution 4.0 International License, which permits use, sharing, adaptation, distribution and reproduction in any medium or format, as long as you give appropriate credit to the original author(s) and the source, provide a link to the Creative Commons license, and indicate if changes were made. The images or other third party material in this article are included in the article's Creative Commons license, unless indicated otherwise in a credit line to the material. If material is not included in the article's Creative Commons license and your intended use is not permitted by statutory regulation or exceeds the permitted use, you will need to obtain permission directly from the copyright holder. To view a copy of this license, visit http://creativecommons.org/ licenses/by/4.0/.

(C) The Author(s) 2021 